observation and principles which have worked like a master-key in opening to our understanding the meaning of this wonderful region. Without those methods and principles it would have been of comparatively little utility to attempt to solve the problems of such a region. Those whose privilege it has been to carry them into practice will ever be glad to acknowledge how great is their indebtedness.

\section{INCLINATION OF THE AXES OF CYCLONES} AND ANTICYCLONES

I HAVE during the last seven years endeavoured, though apparently without much effect, to direct the attention of meteorologists to a law which I conceive to be of very high importance in relation to the theory of the movements of the atmosphere. The law to which I refer is this:- The movements of the upper-currents prove that the axis of a progressive cyclonic circulation is commonly inclined, so that the extremity nearest to the earth's surface is considerably in advance of that in the higher regions of the atmosphere. A barometric minimum consequently occurs at any locality on the earth's surface some hours before the corresponding minimum in the higher regions passes over the same spot ("Laws of the Winds Prevailing in Western Europe," pp. 156 to 162, 1872; Meteorological Magazine, vol. x. pp. 92 to 93, 1875; Quarterly Journal of the Meteorological Society, October, 1877 , pp. 440 to 445 ). I have also pointed out that the axis of an anticyclonic circulation has, at least in some instances, a similar inclination; a point which will be discussed more fully in a future paper.

I hope that the results, strongly confirmatory of this law, which Prof. Loomis has recently derived from his examination of the wind and barometer reports from Mount Washington, Mount Mitchell, and Pike's Peak, will attract more attention than my own deductions from upper-current observations bave done. In his tenth paper of "Contributions to Meteorology" (American Journal of Science and Arts, January, 1879), Prof. Loomis shows that with very few exceptions the barometric minima occur at the base of a mountain considerably earlier than at the summit, the retardation amounting to about one hour for an elevation of from 900 to 1,300 feet, and that the maxima appear to follow the same law.

Other points of agreement between the results of cloud observations in Europe, and those obtained from the reports of the mountain observatories in America, seem to me to be of great interest. I would especially call attention to the substantial coincidence of these results as regards, first, the rarity of easterly upper-currents, as compared with easterly surface-winds; and secondly, the higher, and also less variable, value of the angle made by the northerly, than that made by the westerly uppercurrents, with the direction of the centre of lowest pressure at the earth's surface. W. CLEMENT LEY

\section{BARTOLOMEO GASTALDI}

SINCE the last anniversary of the Geological Society many distinguished men among its members, both in this and foreign countries, have been removed by death. We regret to have to add to the sad list the name of Prof. Gastaldi, the well-known head of the Italian Geological Survey.

Bartolomeo Gastaldi was born at Turin, in the year 1818 , and was originally destined by his father for a legal career; his fondness for geological studies, however, proved too strong to be repressed, and he was eventually entered as a student at the École des Mines at Paris. Here, and throughout his subsequent career, he enjoyed the friendship of Quintino Sella, who afterwards became so distinguished alike in Italian scientific and political circles.
Gastaldi had reached the age of twenty-eight before his first scientific memoir was published, and his earliest essays in this direction were deroted to anatomical and palæontological questions. Before long, however, he seems to bave discovered that the true bent of his genius was towards physical geology. In his studies in this department of science he was greatly aided by his powers as a pedestrian, and he soon made himself familiar with all the southern spurs of the Alpine chain. In company with his friend Sella he founded the Italian Alpine Club, of which he was the second president.

He succeeded Sella as Professor of Geology at the Engineering School of Turin, and subsequently became Professor also at the University. During the later years of his life the work of the Geological Survey, of which he was made director by the Italian Government, occupied much of his attention, and to his energy and capacity much of the success which has already attended that important work is due.

No less than thirty papers on various branches of geological science have proceeded from Gastaldi's pen. He was an advocate, during his later years, of extreme views upon glacial subjects, and many of the views which he propounded on this and on other questions of Alpine geology have not been generally accepted by the geologists of other countries. In some of his speculations, indeed, his boldness seems to have outrun his caution. Those who had the happiness of a personal acquaintanceship with Gastaldi describe him as a most sanguine and earnest student and a warm-hearted friend.

Prof. Gastaldi was a Corresponding Member of the Geological Society of London, and received similar honours from the academies of many other foreign countries. In Turin, where he spent the greater part of his life, and where he occupied the position of a Common Councillor, he was very greatly respected and beloved; this fact is testified to by the circumstance that at his funeral more than three thousand people followed his remains to the cemetery.

\section{ON THE DETERMINATION OF ABSOLUTE PITCH BY THE COMMON HARMONIUM ${ }^{1}$}

THE methods described depend upon the principle that the absolute frequencies of vibration of two musical notes can be deduced from the interval between them, i.e., the ratio of their frequencies, and the number of beats which they occasion in a given time when sounded together. For example, if $x$ and $y$ denote the frequencies of two notes whose interval is an equal temperament major third, we know that $y=1.25992 x$. At the same time the number of beats heard in a second, depending upon the deviation of the third from true intonation, is $4 y-5 x$. In the case of the harmonium these beats are readily counted with the aid of a resonator tuned to the common over-tone, and thus are obtained two equations from which the absolute values of $x$ and $y$ may be found by the simplest arithmetic.

Of course, in practice, the truth of an equal temperament third could not be taken for granted, but the difficulty thence arising would be easily met by including in the counting all the three major thirds which together make up an octave Suppose, for example, that the frequencies of $c, e, g \frac{b}{4} c^{\prime}$ are respectively $x, y, z, 2 x$, and that the beats per second between $x$ and $y$ are $a$, between $y$ and $z$ are $b$, and between $z$ and $2 x$ are $c$. Then,

$$
\begin{aligned}
& 4 y-5 x=a, \\
& 4 z-5 y=b, \\
& 8 x-5 z=c,
\end{aligned}
$$

from which

$$
\begin{aligned}
& x=\frac{1}{3}(25 a+20 b+16 c), \\
& y=\frac{1}{3}(32 a+25 b+20 c), \\
& z=\frac{1}{3}(40 a+32 b+25 c) .
\end{aligned}
$$

- Abstact of a raper read hefore the Murical Assuciation, December *

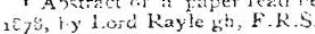

